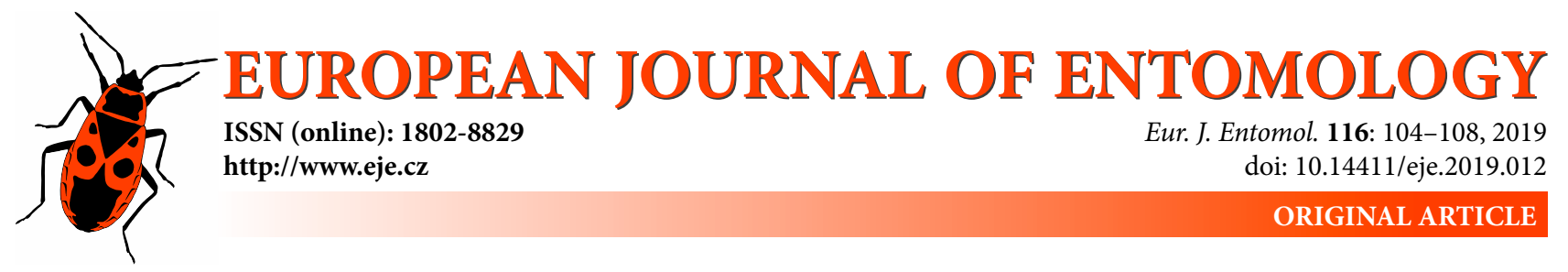

\title{
Daily rhythmicity in the sexual behaviour of Monema flavescens (Lepidoptera: Limacodidae)
}

\author{
Shuzhen YANG ${ }^{1}$, HongXIA LIU ${ }^{2}$, MeIHong YANG ${ }^{2}$ and Jintong ZHANG ${ }^{2, *}$ \\ ${ }^{1}$ Agronomy College, Shanxi Agricultural University, Taigu, Shanxi, 030801, China; e-mail: yangshz2006@163.com \\ ${ }^{2}$ Institute of Chemical Ecology, Shanxi Agricultural University, Taigu, Shanxi, 030801, China; e-mails: sxaulhx@163.com, \\ zxymh123@163.com, zhangjintong@126.com
}

\begin{abstract}
Key words. Lepidoptera, Limacodidae, Monema flavescens, daily rhythmicity, sexual behaviour
Abstract. Daily rhythmicity in the sexual behaviour of Monema flavescens Walker (Lepidoptera: Limacodidae) was studied under laboratory conditions. There was a distinct diel periodicity in female calling, male responsiveness and mating behaviour of $M$. flavescens. As females aged there was an advance in the onset and more time spent calling. One day old females started calling $4 \mathrm{~h}$ after the onset of the scotophase, and 5 to 6 day old females called during the first hour of the scotophase. About $34.5 \%$ of females called on the night they emerged ( 1 day old) and the peak in calling of $97.8 \%$ was recorded for 2 day old females, after which the incidence of calling decreased rapidly with advancing age. Wind tunnel and copulation tests showed that males were sexually mature on the third night and female moths on the second night. The highest value for the percentage mating was recorded for 3 day old virgin females 4 to $6 \mathrm{~h}$ after the onset of the scotophase. In field tests, traps baited with 2 day and 3 day old virgin females captured more males than any other trap and most males were captured 4 to $6 \mathrm{~h}$ ( 1 to 2 day old), 3 to $5 \mathrm{~h}$ ( 3 to 4 day old) and 2 to $4 \mathrm{~h} \mathrm{(5} \mathrm{to} 6$ day old) after the onset of the scotophase. These results indicate that there is a daily rhythm in the reproductive behaviour of $M$. flavescens and provides a better understanding of its sexual behaviour.
\end{abstract}

\section{INTRODUCTION}

The Nettle caterpillar, Monema flavescens Walker, 1855 (Lepidoptera: Limacodidae), is a serious defoliator of a wide variety of trees (Carrillo et al., 2012; Wang et al., 2013; Yang et al., 2016a) in many areas in eastern Asia including Japan, China, Korea and Russia (Siberia) etc. (Lammers, 2004; Yang et al., 2016b). Currently, $M$. flavescens is increasing in abundance in China and overwintering cocoons are easily found in orchards and parks (Ju et al., 2008; Li et al., 2010, 2013; Han et al., 2013). Currently, the control of this insect pest relies mainly on spraying with chemical insecticides. However, as apples, pears and other fruit mature when the larvae of this pest are most active using pesticides to control them poses serious problems. Use of the female-produced sex pheromone may offer a promising alternative tool for controlling this pest. As recorded for other pests (Blackmer et al., 2008; Jing et al., 2010; Yang et al., 2012; Youm et al., 2012; Naka et al., 2018), sex pheromones could provide an environmentally friendly and effective technique for controlling these pests by selectively capturing the males and so reducing the likelihood of females finding a mate.
In this study, daily rhythmicity and the effects of age on both calling behaviour were investigated in M. flavescens. These studies could be helpful in improving our understanding of chemical communication in the reproductive behaviour of Chinese populations of $M$. flavescens and of how to use pheromones to detect, monitor and mass-capture this pest in the field.

\section{MATERIALS AND METHODS}

\section{Insects}

Cocoons were collected from pear and apple trees in Luanxian County, Hebei Province, in late April 2014 and 2015. The cocoons were kept at $25 \pm 2{ }^{\circ} \mathrm{C}, 75 \pm 5 \%$ relative humidity $(\mathrm{RH})$ and under a natural photoperiod until adult emergence. The adults of M. flavescens started to emerge at the end of May. After emergence, the male and female moths were immediately segregated into different cages $(40 \times 40 \times 60 \mathrm{~cm} ; 15$ moths per cage $)$ containing $10 \%(\mathrm{wt} / \mathrm{vol})$ sugar solution in different rooms. One room was used for observing calling and copulation and the other for wind tunnel experiments under a 14L : 10D natural photoperiod (sunrise about at 5:00 and sunset at 19:00). A single red incandescent light bulb providing a light intensity of approximately 0.5 lux was used to observe sexual behaviour in both rooms. In-

\footnotetext{
* Corresponding author; e-mail: zhangjintong@126.com.
} 
dividuals were considered to be 1 day old $(1 \mathrm{~d})$ between 0 and 24 $\mathrm{h}$ after emergence.

\section{Calling behaviour}

Observations of $30 \mathrm{M}$. flavescens females were made every 15 min throughout the $10 \mathrm{~h}$ of the scotophase because preliminary observations indicated that adults were not sexually active during the photophase. Calling behaviour of female moths was accompanied by the full exposure of their ovipositors. If a female called during two consecutive observations, it was considered to have been calling for $30 \mathrm{~min}$. If a female was recorded calling on only one of the two observations, it was considered to have been calling for $15 \mathrm{~min}$. Calling behaviour was recorded on three occasions (three replicates) for a total of 90 females.

\section{Wind tunnel tests}

The wind tunnel experiments were performed in a glass wind tunnel $(195 \times 60 \times 60 \mathrm{~cm})$ maintained at $22 \pm 2^{\circ} \mathrm{C}$ and $75 \% \pm$ $3 \% \mathrm{RH}$, with an air speed of $0.5 \mathrm{~m} / \mathrm{s}$ and a light intensity of approximately 0.5 lux. Extract of the pheromone glands of five females was reduced to $10 \mu \mathrm{L}$ under a gentle stream of $\mathrm{N}_{2}$ and then dispensed onto a $2.0 \mathrm{~cm}^{2}$ filter paper placed in the wind tunnel. The response of $M$. flavescens males was tested daily using moths aged from 1 to 6 days old, at different times during the scotophase and when they were most sexually active ( 3 day old). The males were acclimated for at least $1 \mathrm{~h}$ to the light intensity and airflow in the tunnel before they were exposed to the pheromone. The males were released $150 \mathrm{~cm}$ downwind from the pheromone source. Two minutes were allotted for the male to respond and when there was no response the male was replaced. Once flight was initiated, the males were observed until they stopped responding. All treatments were tested in random order with three replicates, with each replicate consisting of approximately 15 males. The responses of the males was recorded in terms of the following behaviour: takeoff, directed flight, landing on the source and attempts at copulation.

\section{Copulation}

In order to record mating activity, six groups of 20 pairs of 1 to 6 day old virgin males and females were placed individually in small cages $(60 \times 60 \times 60 \mathrm{~cm})$ and mating recorded every $15 \mathrm{~min}$ during the test period. All these experiments were done in a test room at $25 \pm 1{ }^{\circ} \mathrm{C}, 75 \pm 1 \%$ R.H and under a $14 \mathrm{~L}: 10 \mathrm{D}$ photoperiod. Mating pairs were gently transferred into a small cage (30 $\times 30 \times 30 \mathrm{~cm}$ ) for measuring copulation duration. Mating pairs and the other moths were not disturbed during this process. When the scotophase ended at 5 a.m., females were dissected, and copulation was determined by the presence of a spermatophore. The percentages of pairs starting to copulate at different times during

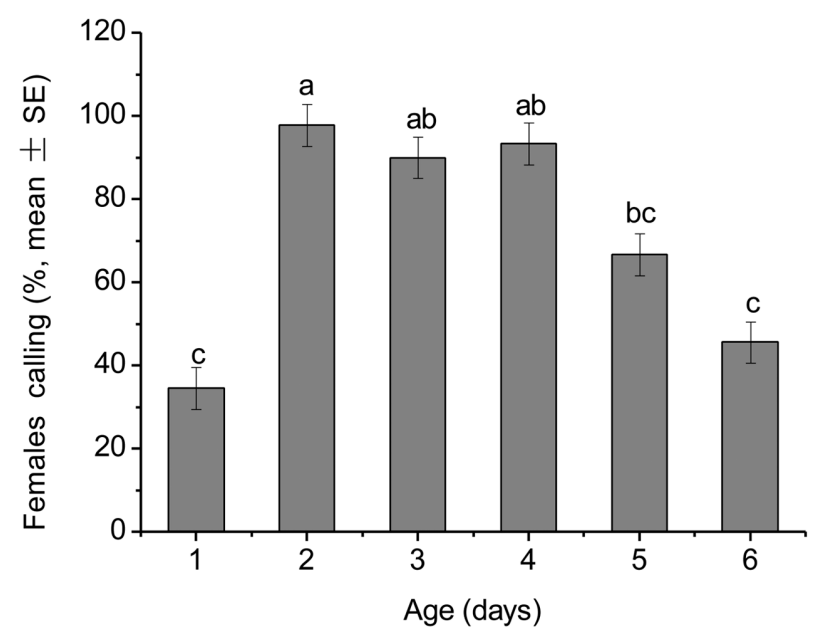

Fig. 1. The percentage of females of Monema flavescens of different ages calling during the scotophase. Percentages are means $( \pm$ $\mathrm{SE})$. The different letters indicate significant differences at $\mathrm{P} \leq 0.05$ according to Tukey's HSD of arcsine-transformed data.

the scotophase were calculated for all the groups. Three replicate groups were observed, with a total of 60 pairs in each group.

\section{Field tests}

Field tests were conducted in pear trees in Luanxian County, Hebei Province $\left(39^{\circ} 66^{\prime} \mathrm{N}, 118^{\circ} 72^{\prime} \mathrm{E}\right)$, in June 2014 . White delta sticky traps were suspended at a height of $1.5 \mathrm{~m}$ at intervals of 50 $\mathrm{m}$. Virgin females aged 1 to 6 days old were placed in cages as bait beneath the roof of the traps. To compare the attractiveness of the virgin females, control traps without females were also used. The trap catches were counted every hour, and the moths on the sticky traps were recorded. The distribution of the treatments was randomized within six replicate series, using a total of 42 traps.

\section{Data analyses}

The statistical analyses were performed using the SPSS 19.0 statistical software package (SPSS Inc., Chicago, IL, USA). Analyses of variance (ANOVA) and Duncan's multiple range test were used to assess the effect of age on the time spent calling. The percentages of moths calling, wind tunnel and copulation results were analyzed using Tukey's Honestly Significantly Different (HSD) tests of arcsine-transformed data. The data on the number of moths captured in the field were analyzed using nonparametric Friedman test analysis of variance followed by Bonferroni corrections. The level of significance in all tests was set at 0.05 .

Table 1. Percentage (\%) of females of Monema flavescens of different ages recorded calling at different times after the onset of the scotophase.

\begin{tabular}{ccccccc}
\hline \multirow{2}{*}{ Scotophase $(\mathrm{h})$} & \multicolumn{7}{c}{ Percentage of Monema flavescens females calling (\%, mean \pm SE) } \\
\cline { 2 - 7 } & 1-day old & 2-day old & 3-day old & 4-day old & 5-day old & 6-day old \\
\hline D0 1 & $0.0 \pm 0.0 \mathrm{~b}$ & $0.0 \pm 0.0 \mathrm{c}$ & $0.0 \pm 0.0 \mathrm{~d}$ & $0.0 \pm 0.0 \mathrm{~d}$ & $4.5 \pm 2.2 \mathrm{~d}$ & $2.2 \pm 2.2 \mathrm{~b}$ \\
D1 2 & $0.0 \pm 0.0 \mathrm{~b}$ & $0.0 \pm 0.0 \mathrm{c}$ & $0.0 \pm 0.0 \mathrm{~d}$ & $15.6 \pm 8.0 \mathrm{~d}$ & $17.8 \pm 2.2 \mathrm{bcd}$ & $13.3 \pm 5.1 \mathrm{ab}$ \\
D2 3 & $0.0 \pm 0.0 \mathrm{~b}$ & $10.0 \pm 5.8 \mathrm{bc}$ & $16.7 \pm 8.4 \mathrm{~d}$ & $62.2 \pm 6.7 \mathrm{bc}$ & $42.2 \pm 5.9 \mathrm{abcd}$ & $32.2 \pm 9.1 \mathrm{ab}$ \\
D3 4 & $2.2 \pm 2.2 \mathrm{~b}$ & $31.1 \pm 5.9 \mathrm{~b}$ & $55.5 \pm 2.2 \mathrm{bc}$ & $78.9 \pm 2.9 \mathrm{ab}$ & $53.3 \pm 7.7 \mathrm{ab}$ & $41.1 \pm 10.6 \mathrm{a}$ \\
D4 5 & $7.8 \pm 4.8 \mathrm{ab}$ & $64.5 \pm 9.1 \mathrm{a}$ & $81.1 \pm 1.1 \mathrm{a}$ & $91.1 \pm 4.0 \mathrm{a}$ & $60.0 \pm 9.6 \mathrm{a}$ & $41.1 \pm 9.7 \mathrm{a}$ \\
D5 6 & $17.8 \pm 4.5 \mathrm{a}$ & $61.1 \pm 4.8 \mathrm{a}$ & $70.0 \pm 6.7 \mathrm{ab}$ & $75.6 \pm 10.6 \mathrm{ab}$ & $52.2 \pm 10.6 \mathrm{abc}$ & $36.7 \pm 8.8 \mathrm{ab}$ \\
D6 7 & $2.2 \pm 1.1 \mathrm{~b}$ & $21.1 \pm 1.1 \mathrm{bc}$ & $44.5 \pm 6.2 \mathrm{c}$ & $30.0 \pm 8.8 \mathrm{~cd}$ & $32.2 \pm 8.0 \mathrm{abcd}$ & $22.2 \pm 6.2 \mathrm{ab}$ \\
D7 8 & $3.3 \pm 3.3 \mathrm{~b}$ & $3.3 \pm 3.3 \mathrm{c}$ & $14.4 \pm 2.9 \mathrm{~d}$ & $11.1 \pm 4.0 \mathrm{~d}$ & $16.6 \pm 6.7 \mathrm{~cd}$ & $6.7 \pm 1.9 \mathrm{ab}$ \\
D8 10 & $1.1 \pm 1.1 \mathrm{~b}$ & $2.2 \pm 2.2 \mathrm{c}$ & $6.7 \pm 1.9 \mathrm{~d}$ & $1.1 \pm 1.1 \mathrm{~d}$ & $5.6 \pm 2.9 \mathrm{~d}$ & $2.2 \pm 1.1 \mathrm{~b}$ \\
\hline
\end{tabular}

There were three replicates of each of the observations throughout the scotophase $(N=30)$. The different letters within columns indicate significant differences at $\mathrm{P} \leq 0.05$ according to Tukey's HSD of arcsine-transformed data. 


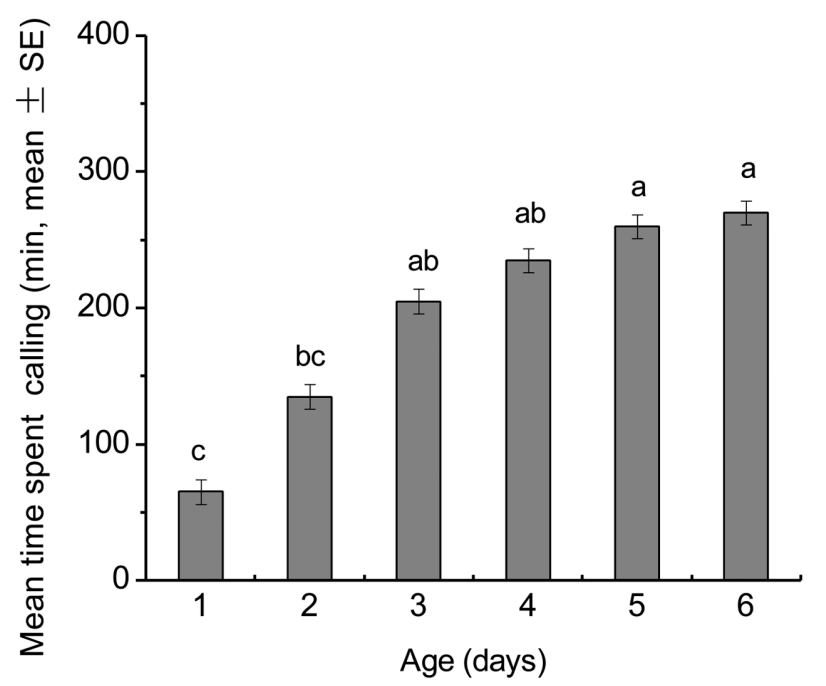

Fig. 2. The mean time females of Monema flavescens of different ages spent calling in the scotophase. Values are means $( \pm S E)$. Values followed by different letters are significantly different $(P \leq$ 0.05 ) based on Duncan's multiple range test.

\section{RESULTS}

\section{Calling behaviour}

Calling behaviour of females of $M$. flavescens of different ages was recorded at different times during the scotophase (Table 1). Females of M. flavescens were only sexually active during the scotophase. Calling activity of 1 day old females ( 1 day old) started $3 \mathrm{~h}$ after the onset of the scotophase, and the mean time of the onset of calling occurred earlier as they increased in age. The 5 to 6 day old females called throughout the scotophase. Only $34.5 \%$ of the females called on the night ( 1 day old) after emergence, whereas almost all females $(97.8 \%)$ called on the next night ( 2 day old) (Fig. 1). The percentage of females calling significantly declined on the 5 th night after emergence when about $66.7 \%$ of females called. The mean time spent calling increased significantly with age (Fig. 2).

\section{Wind tunnel experiments}

The first weak response of $M$. flavescens males to the sex pheromone occurred on the night after emergence and the peak response on the third night (Table 2). Males responded to the pheromone throughout the scotophase, but the peak response occurred 4 to $6 \mathrm{~h}$ after the onset of the scotophase (Table 3).

Table 2. Effect of age on response (\%) of Monema flavescens males to pheromone extracts in a wind tunnel.

\begin{tabular}{ccccc}
\hline \multirow{2}{*}{$\begin{array}{c}\text { Age } \\
\text { (days) }\end{array}$} & \multicolumn{4}{c}{ Response of Monema flavescens males (\%, mean \pm SE) } \\
\hline 1 & $53.3 \pm 3.8 \mathrm{c}$ & $33.3 \pm 3.8 \mathrm{c}$ & $17.8 \pm 2.2 \mathrm{~d}$ & $13.3 \pm 0.0 \mathrm{~d}$ \\
2 & $84.4 \pm 5.9 \mathrm{bc}$ & $73.3 \pm 3.8 \mathrm{~b}$ & $35.5 \pm 2.2 \mathrm{~cd}$ & $31.1 \pm 2.2 \mathrm{~cd}$ \\
3 & $100.0 \pm 0.0 \mathrm{a}$ & $95.5 \pm 2.2 \mathrm{a}$ & $80.0 \pm 3.9 \mathrm{a}$ & $75.5 \pm 2.2 \mathrm{a}$ \\
4 & $97.8 \pm 2.2 \mathrm{ab}$ & $91.1 \pm 2.2 \mathrm{ab}$ & $73.4 \pm 6.7 \mathrm{ab}$ & $66.7 \pm 6.7 \mathrm{ab}$ \\
5 & $93.3 \pm 3.8 \mathrm{ab}$ & $86.7 \pm 3.8 \mathrm{ab}$ & $55.5 \pm 2.2 \mathrm{bc}$ & $51.1 \pm 2.2 \mathrm{bc}$ \\
6 & $86.7 \pm 3.8 \mathrm{~b}$ & $75.5 \pm 2.2 \mathrm{~b}$ & $44.4 \pm 5.9 \mathrm{c}$ & $35.6 \pm 4.4 \mathrm{c}$ \\
\hline
\end{tabular}

The different letters within columns indicate significant differences at $\mathrm{P} \leq 0.05$ according to Tukey's HSD of arcsine-transformed data.

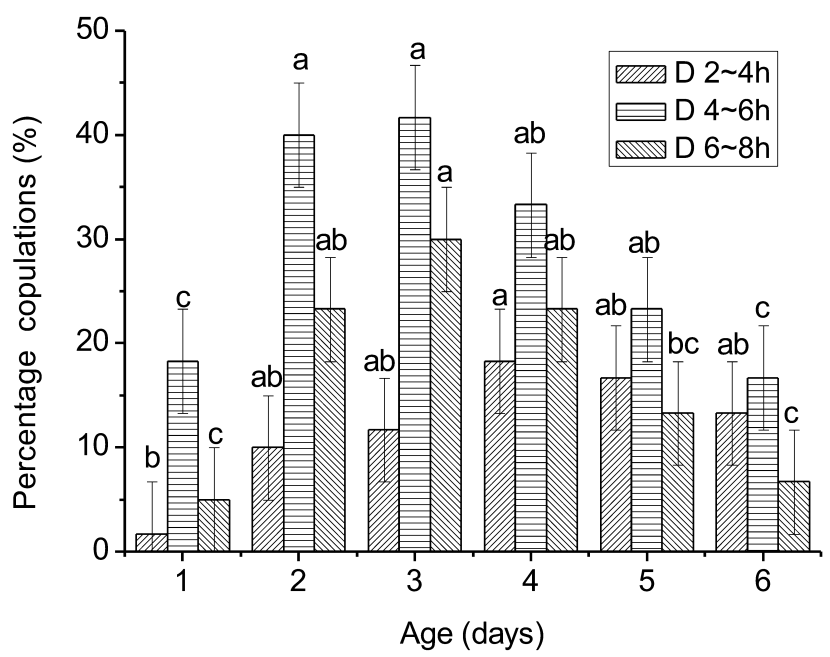

Fig. 3. The percentage of Monema flavescens of different ages recorded mating at different times after the onset of the scotophase. Values are means $( \pm S E)$. Values followed by different letters are significantly different $(P \leq 0.05)$ based on Tukey's HSD of arcsinetransformed data.

\section{Copulation}

M. flavescens was only observed copulating during the scotophase. Copulations were first recorded at the beginning of the second hour and reached a peak about 4 to 6 $\mathrm{h}$ into the scotophase (Fig. 3). The percentage mating was significantly dependant on the age of the virgin females. The percentage was highest for 3 day old moths (41.7\%), followed by 2 day old (40\%), 4 day old (33.3\%), 5 day old $(23.3 \%), 1$ day old $(18.3 \%)$, and 6-d-old (16.7\%). The average duration of copulation was $120.8 \pm 12.6 \mathrm{~min}$ (mean \pm $\mathrm{SE} ; \mathrm{N}=20$ ) and ranged from 60 to $240 \mathrm{~min}$.

\section{Field tests}

Unbaited traps set during the scotophase and traps baited with virgin female set during the photophase failed to attract males of $M$. flavescens in the field. Traps baited with 2 day old and 3 day old virgin females captured more males than the other traps (Table 4). The number of males captured significantly depended on the age of the virgin females and the time from the onset of the scotophase. Most males were captured in traps 4 to $6 \mathrm{~h}$ ( 1 to 2 day old fe-

Table 3. Effect of time after the onset of the scotophase on the response (\%) of Monema flavescens males to pheromone extracts in a wind tunnel.

\begin{tabular}{ccccc}
\hline \multirow{2}{*}{$\begin{array}{c}\text { Hour of } \\
\text { scotophase }\end{array}$} & \multicolumn{4}{c}{$\begin{array}{c}\text { Response of Monema flavescens males } \\
(\%, \text { mean } \pm \text { SE) }\end{array}$} \\
\cline { 2 - 5 } & Take off & $\begin{array}{c}\text { Directed } \\
\text { flight }\end{array}$ & Landing & $\begin{array}{c}\text { Copulation } \\
\text { attempts }\end{array}$ \\
\hline $0 \sim 2$ & $44.5 \pm 11.8 \mathrm{~b}$ & $33.3 \pm 3.8 \mathrm{~b}$ & $13.3 \pm 3.8 \mathrm{c}$ & $6.7 \pm 3.8 \mathrm{~b}$ \\
$2 \sim 4$ & $77.8 \pm 4.5 \mathrm{~b}$ & $64.3 \pm 5.9 \mathrm{~b}$ & $40.0 \pm 3.8 \mathrm{~b}$ & $31.1 \pm 5.9 \mathrm{~b}$ \\
$4 \sim 6$ & $100.0 \pm 0.0 \mathrm{a}$ & $93.3 \pm 3.8 \mathrm{a}$ & $77.8 \pm 4.5 \mathrm{a}$ & $71.1 \pm 5.9 \mathrm{a}$ \\
$6 \sim 10$ & $73.3 \pm 7.7 \mathrm{~b}$ & $62.2 \pm 5.9 \mathrm{~b}$ & $37.8 \pm 2.3 \mathrm{~b}$ & $28.9 \pm 2.2 \mathrm{~b}$ \\
$8 \sim 10$ & $33.3 \pm 5.9 \mathrm{c}$ & $28.9 \pm 3.8 \mathrm{c}$ & $13.3 \pm 2.2 \mathrm{c}$ & $6.7 \pm 5.9 \mathrm{~b}$ \\
\hline
\end{tabular}

The Monema flavescens males tested were 3 days old $(\mathrm{N}=45)$. The different letters within columns indicate significant differences at $\mathrm{P} \leq 0.05$ according to Tukey's HSD of arcsine-transformed data. 
Table 4. Effect of the photophase and the time after the onset of the scotophase on catches of male M. flavescens in traps baited with 1 to 6 day old virgin females.

\begin{tabular}{|c|c|c|c|c|c|c|c|}
\hline \multirow{2}{*}{$\begin{array}{c}\text { Photophase (L) } \\
\text { Scotophase (D) } \\
(\mathrm{h})\end{array}$} & \multicolumn{7}{|c|}{ Males captured / trap (mean \pm SE) } \\
\hline & 1-day old & 2-day old & 3-day old & 4-day old & 5-day old & 6-day old & Not baited \\
\hline L0 14 & $0.0 \mathrm{c}$ & $0.0 \mathrm{~d}$ & $0.0 \mathrm{~d}$ & $0.0 a$ & $0.0 \mathrm{c}$ & $0.0 \mathrm{~b}$ & 0.0 \\
\hline Do 1 & $0.0 c$ & $0.0 \mathrm{~d}$ & $0.0 \mathrm{~d}$ & $0.0 \mathrm{a}$ & $0.0 \mathrm{c}$ & $0.0 \mathrm{~b}$ & 0.0 \\
\hline D1 2 & $0.0 c$ & $0.0 \mathrm{~d}$ & $0.0 \mathrm{~d}$ & $0.0 \mathrm{a}$ & $0.3 \pm 0.5 a b c$ & $0.3 \pm 0.5 a b$ & 0.0 \\
\hline D2 3 & $0.0 c$ & $0.0 \mathrm{~d}$ & $0.0 \mathrm{~d}$ & $0.7 \pm 0.5 a$ & $1.8 \pm 1.5 a$ & $0.8 \pm 0.7 a$ & 0.0 \\
\hline D3 4 & $0.3 \pm 0.5 a b c$ & $1.2 \pm 0.7 b c$ & $2.3 \pm 1.7 a b$ & $2.3 \pm 2.1 \mathrm{a}$ & $1.3 \pm 1.2 \mathrm{abc}$ & $0.3 \pm 0.5 a b$ & 0.0 \\
\hline D4 5 & $1.5 \pm 1.0 \mathrm{a}$ & $3.5 \pm 1.8 a$ & $3.2 \pm 1.6 a$ & $2.0 \pm 2.2 a$ & $0.5 \pm 0.5 a b c$ & $0.0 \mathrm{~b}$ & 0.0 \\
\hline D5 6 & $1.2 \pm 1.2 \mathrm{ab}$ & $2.2 \pm 1.4 a b$ & $1.2 \pm 0.7 b c$ & $0.8 \pm 1.2 a$ & $0.2 \pm 0.4 b c$ & $0.0 \mathrm{~b}$ & 0.0 \\
\hline D6 7 & $0.7 \pm 0.8 a b c$ & $0.8 \pm 0.7 \mathrm{bcd}$ & $0.3 \pm 0.5 \mathrm{~cd}$ & $0.0 a$ & $0.0 c$ & $0.0 \mathrm{~b}$ & 0.0 \\
\hline D7 10 & $0.0 \mathrm{c}$ & $0.0 \mathrm{~d}$ & $0.0 \mathrm{~d}$ & $0.0 a$ & $0.0 \mathrm{c}$ & $0.0 \mathrm{~b}$ & 0.0 \\
\hline Total & $3.7 \pm 1.4 \mathrm{ab}$ & $7.7 \pm 2.1 \mathrm{a}$ & $7.0 \pm 1.9 a$ & $5.8 \pm 1.5 a b$ & $4.1 \pm 2.7 a b$ & $1.4 \pm 2.0 b$ & 0.0 \\
\hline
\end{tabular}

Means in a column followed by different letters are significantly different after Bonferroni correction $(1 \mathrm{day}$ old: $\mathrm{H}=30.5$, d.f. $=8$, $\mathrm{P}=0.000$; 2 days old: $\mathrm{H}=38.9$, d.f. $=8, \mathrm{P}=0.000 ; 3$ days old: $\mathrm{H}=38.0$, d.f. $=8, \mathrm{P}=0.000 ; 4$ days old: $\mathrm{H}=29.7, \mathrm{~d} . \mathrm{f} .=8, \mathrm{P}=0.000 ; 5$ days old: $\mathrm{H}=$ 27.7, d.f. $=8, \mathrm{P}=0.001 ; 6$ days old: $\mathrm{H}=21.5$, d.f. $=8, \mathrm{P}=0.006)$.

males), 3 to $5 \mathrm{~h}$ ( 3 to 4 day old) and 2 to $4 \mathrm{~h}$ (5 to 6 day old) after the onset of the scotophase (Table 4).

\section{DISCUSSION}

Female calling, male responsiveness and mating behaviour of M. flavescens had a distinct diel periodicity. Under natural conditions, $34.5 \%$ of the females that called during the first night were fertilized that night, the number of females calling on the second night was $97.8 \%$, and the number of females older than 2 days recorded calling was almost zero. These results indicate that most female moths were sexually mature on the second night. One day old females started calling $3 \mathrm{~h}$ after the onset of the scotophase, but 5 to 6 day old females called during the first hour of the scotophase. The result that females began calling earlier during the scotophase and for a longer time as they aged is in agreement with that recorded for several other species of moths (Seol et al., 1986; Delisle, 1992; Spurgeon et al., 1995; Mazor \& Dunkelblum, 2005). Older females advance their calling time to increase their mating success relative to younger females, otherwise they would be at a disadvantage compared to the younger females if they did not spend more time calling (Delise, 1995; Xiang et al., 2010; Liu, 2013).

Wind tunnel and copulations tests indicate that the males were sexually mature on the third night, one day later than female moths. This accounts for why most 2 day old females called but were less likely to be mated than 3 day old females. Similar results are reported for the insect tomato looper, Chrysodeixis chalcites (Snir et al., 1986).

Field tests indicate that none of the traps caught male moths during the day, but were most attractive 4 to $6 \mathrm{~h}$ (1 to 2 day old), 3 to $5 \mathrm{~h}$ ( 3 to 4 day old) and 2 to $4 \mathrm{~h}$ (5 to 6 day old) after the onset of darkness, respectively. These results also indicate that the diel periodicity in calling conform with the result of the field tests, and similar results are reported for Maruca vitrata (Lu et al., 2007) and Isoceras sibirica (Lu et al., 2013).

The calling and mating in Lepidoptera have a certain rhythm. Studying the rhythm of their reproductive behaviour can provide an important theoretical basis for the ef- fective control of insects and reducing the economic losses they cause. However, the effects of some other factors such as temperature and photoperiod should also be studied in the future.

ACKNOWLEDGEMENTS. This work was supported by the Natural Science Foundation for Young Scientists of Shanxi Province in China (Grant No. 201701D221184) and Research Foundation of the Introduction of Talents of Shanxi Agricultural University (Grant no. 2017ZZ03).

\section{REFERENCES}

Blackmer J.L., Byers J.A. \& Rodriguez-Saona C. 2008: Evaluation of color traps for monitoring Lygus spp.: Design, placement height, time of day, and non-target effects. - Crop Prot. 27: 171-181.

Carrillo J., Wang Y., Ding J. \& Siemann E. 2012: Induction of extrafloral nectar depends on herbivore type in invasive and native Chinese tallow seedlings. - Basic Appl. Ecol. 13: 449-457.

Delisle J. 1992: Age related changes in the calling behaviour and the attractiveness of obliquebanded leafroller virgin females, Choristoneura rosaceana, under different constant and fluctuating temperature conditions. - Entomol. Exp. Appl. 63: $55-62$.

DelisLe J. 1995: Effect of male and female age on the mating success of the oblique-banded leafroller Choristoneura rosaceana (Lepidoptera: Tortricidae) under different ecological conditions. - J. Insect Behav. 8: 781-799.

Jing X.Y., Zhang J.T., Luo Y.Q., Zong S.X. \& Liu P.H. 2010: Synthesis and biological activity evaluation of sex attractant for Holcocerus arenicola (Lepidoptera: Cossidae). - Sci. Silvae Sin. 46: 87-92.

Ju R.T., Li Y.Z., Wang F., Du Y.Z. \& ZHu F. 2008: Effect of temperature and relative humidity on eclosion of overwintering adults of Monema flavescens. - Chin. Bull. Entomol. 45: 70-74.

Lammers J.W. \& Stigter H. 2004: Pest Risk Analysis - Cnidocampa flavescents. Plant Protection Service - The Netherlands, Wageningen, $12 \mathrm{pp}$.

Li J.J., Li X.L., Feng J.N., Li D.H. \& HuA L. 2010: Spatial distrbution pattern and sampling technique of Cnidocanpa flavescens larva in walnut. — J. Anhui Agric. Sci. 38: 21074-21078.

Li Z.W., Guo Y.H., Qiu F.C., Li P., Wang D.J. \& Li S.Z. 2013: Occurrence and comprehensive prevention and control tech- 
nology of Monema flavescens in jujube orchard of Lingwu, Ningxia Hui Autonomous Region. - China Fruits 2: 58-60.

Liu H.X., Zhao W.M., Yang M.H., Liu J.L. \& Zhang J.T. 2013 Diel rhythms of sexual behavior and pheromone titers in Isoceras sibirica Alpheraky (Lepidoptera, Cossidae). — Arch. Insect Biochem. 84: 15-26.

Lu P.F., Qiao H.L., Wang X.P., Zhou X.M., Wang X.Q. \& Lei C.L. 2007: Adult behavior and circadian rhythm of sex pheromone production and release of the legume pod borer, Maruca vitrata (Fabricius) (Lepidoptera: Pyralidae). - Acta Entomol. Sin. 50: 335-342.

Mazor M. \& DunKelblu E. 2005: Circadian rhythms of sexual behavior and pheromone titers of two closely related moth species, Autographa gamma and Cornutiplusia circumflexa. - J. Chem. Ecol. 31: 2153-2168.

Naka H., Kubota S., Kuchiki F., Shibasaki H., Yamamoto M., Soejima Y., Arita Y. \& Ando T. 2018: Identification and field attraction of the female sex pheromone of a kiwifruit pest, Nokona feralis (Lepidoptera: Sesiidae). - J. Chem. Ecol. 44: $1-11$.

Seol K.Y., Honda H. \& Matsumoto Y. 1986: Mating behavior and sex pheromone of the lesser mulberry pyralid, Glyphodes pyloalis Walker (Lepidoptera: Pyralidae). - Appl. Entomol. Zool. 21: 228-235.

Snir R., Dunkelblum E., Gothilf S. \& Harpaz I. 1986: Sexual behaviour and pheromone titre in the tomato looper, Plusia chalcites (Esp.) (Lepidoptera: Noctuidae). - J. Insect Physiol. 32: $735-739$.
Spurgeon D.W., Lingren P.D., Raulston J.R. \& Shaver T.N. 1995: Age-specific mating activities of Mexican rice borers (Lepidoptera: Pyralidae). — Environ. Entomol. 24: 106-109.

Wang Y., Carrillo J., Siemann E., Wheeler G.S., Zhu L., Gu X. \& DiNG J. 2013: Specificity of extrafloral nectar induction by herbivores differs among native and invasive populations of tallow tree. - Ann. Bot. 112: 751-756.

XIANG Y.Y., YANG M.F. \& Li Z.Z. 2010: Calling behavior and rhythms of sex pheromone production in the black cutworm moth in China. - J. Insect Behav. 23: 35-44.

Yang M.H., Zhang J.T., Zong S.X. \& Luo Y.Q. 2012: Synthesis and field evaluation of sex attractants of Holcocerus vicarius (Lepidoptera: Cossidae). - Sci. Silvae Sin. 48: 61-66.

Yang S.Z., Liu H.X., Yang M.H., Zhang J.T., Li Z.W., Jing X.Y. \& ZHENG H.X. 2016a: Female sex pheromone of a nettle caterpillar, Monema flavescens, in China. - Entomol. Exp. Appl. 161: 161-167.

YANG S.Z., Liu H.X., Zheng H.X., YANG M.H., ReN Y.X. \& ZHANG J.T. 2016b: Attraction of Monema flavescens males to synthetic blends of sex pheromones. - Bull. Insectol. 69: 193-198.

Youm O., Maliki Y., Hall D.R., Farman D.I. \& Foster J.E. 2012: Pheromone-mediated mating disruption in the millet stem borer, Coniesta ignefusalis (Lepidoptera: Pyralidae). - Crop Prot. 31: 50-57.

Received November 2, 2018; revised and accepted March 5, 2019 Published online April 11, 2019 